\title{
Analisis Karakter "Kreativitas" siswa kelas VIII SMPN 08 Kota Jambi
}

\author{
Prita Monalisa ${ }^{1}$, Weni Sukarni ${ }^{2}$ \\ ${ }^{1}$ SMPN 1 V Koto Kampung Dalam, Kabupaten Padang Pariaman, Provinsi Sumatera Barat \\ ${ }^{2}$ Prodi Pendidikan Fisika FKIP Universitas Jambi \\ ${ }^{1}$ prita.monalisa27@gmail.com \\ ${ }^{2}$ wenisukarni282.ws@gmail.com
}

\begin{abstract}
ABSTRAK
Penelitian ini bertujuan untuk menganalisis karakter siswa, khususnya karakter kreativitas siswa kelas VIII SMPN 08 Kota Jambi. Penelitian ini menggunakan metode penelitian kuantitatif deskriptif. Sedangkan jenis penelitian yang digunakan adalah survei dengan instrumen penilaian tes berupa angket dengan variable karakter kreativitas. Subjek penelitian ini adalah siswa kelas VIII C dan VIII E SMPN 08 Kota Jambi, dengan jumlah total responden sebanyak 59 responden. Teknik pengambilan sampel menggunakan total sampling yaitu jumlah sampel sama dengan populasi. Adapun hasil penelitian menyatakan bahwa angket kreativitas siswa kelas VIII C rata-rata tergolong dalam kategori "Tidak Baik" dengan 58,1 \% pernyataan dijawab tidak baik oleh siswa dan 35,5\% pernyataan dijawab dengan baik oleh siswa. Sedangkan hasil penelitian pada kelas VIII E rata-rata tergolong dalam kategori "Baik" dengan 60,7 \% pernyataan dijawab baik oleh siswa dan 32,1\%, dijawab tidak baik oleh siswa. Berdasarkan hasil angket tersebut, dapat disimpulkan bahwa tingkat kreativitas siswa kelas VIII C lebih rendah dari kelas VIII E.
\end{abstract}

Kata kunci: Karakter, Kreativitas Siswa, Pendidikan

\section{ABSTRACT}

This study was intended to analyze the character of students, the special characteristics of creativity of class VIII students of SMPN 08 Jambi City. This study uses descriptive quantitative research methods. While the type of research used is observation with the assessment instrument in the form of a questionnaire with character variables of creativity. The subjects of this study were students of class VIII C and VIII E of SMPN 08 Jambi City, with a total number of respondents as many as 59 respondents. The sampling technique uses total sampling, namely the number of samples equal to the population. Class VIII C on average falls into the category of "Not Good" with $58.1 \%$ of statements answered not well by students and 35.5\% of statements answered well by students. While the results of research in class VIII E are categorized as "Good" on average with 60.7\% of statements answered well by students and $32.1 \%$ of statements answered not well by students. Based on the results of the questionnaire, it can be concluded that the level of creativity of class VIII C students is lower than class VIII E.

Keywords: Character, Student Creativity, Education

\section{PENDAHULUAN}

Salah satu sarana yang berperan penting dalam perubahan anak bangsa adalah pendidikan. Menurut Sumarni, dkk (2017: 21), Pendidikan adalah salah satu sarana yang mendukung setiap peserta didik untuk mengembangkan minat, bakat dan kemampuannya secara optimal dan utuh meliputi ranah kognitif, afektif, dan psikomotor. Menurut Siagian dan Nurfitriyanti (2015: 37), Pendidikan adalah usaha secara sadar untuk mengembangkan potensi sumber daya manusia. Oleh karena itu, pendidikan merupakan satu-satunya cara agar manusia dapat menjadi lebih baik dalam meningkatkan sumber daya manusia, sehingga dapat mengimbangi setiap perkembangan yang terjadi agar tidak tertinggal jauh oleh kemajuan zaman dalam segala aspek.

Salah satu ilmu pengetahuan yang dapat meningkatkan prestasi pendidikan peserta didik melalui pembelajaran sains adalah Ilmu Pengetahuan Alam. Menurut Puti dan Jumadi (2015: 80), Upaya untuk memperoleh suatu 
pemahaman, penyadaran, dan pengembangan nilai positif tentang hakikat sains melalui pembelajaran Ilmu Pengetahuan Alam (IPA). Sedangkan Menurut Taufik, dkk (2010: 33), Pembelajaran IPA terutama Fisika merupakan pembelajaran yang menjadi salah satu faktor pendukung dalam penerapan IPA Terpadu sebagai sains. Pada dasarnya sains terdiri dari produk, proses, dan sikap ilmiah. Pembelajaran IPA bidang fisika seharusnya mampu memberikan pengalaman langsung kepada siswa agar dapat meningkatkan kemampuan siswa dalam memperbaiki, memahami, dan menerapkan konsep yang telah dipelajari. Sehingga, siswa memiliki kemampuan dalam menemukan sendiri berbagai konsep secara keseluruhan, bermakna, dipercaya serta aplikatif untuk kepentingan pemecahan masalah. Sementara itu Menurut Taufiq, dkk (2014: 141), Dalam pembelajaran IPA terpadu terdapat beberapa konsep yang relevan, sehingga penggunaan waktunya dapat lebih efisien dan pencapaian tujuan pembelajaran lebih efektif. Salah satu upaya penerapannya melalui pengembangan media pembelajaran IPA berkarakter. Oleh karena itu, pendidikan IPA dapat direalisasikan melalui berbagai upaya, salah satunya yaitu melalui pembelajaran IPA. Pembelajaran IPA memiliki potensi yang sangat besar dalam upaya membangun bangsa, Namun ternyata selama ini hanya dianggap sebagai beban berat yang kurang disenangi oleh peserta didik dan terabaikan (Rahayu dan Laksono, 2015: 30).

Hal yang mendukung terjadinya proses pembelajaran adalah karakter. Karakter merupakan faktor dorongan untuk menentukan pilihan yang terbaik dalam hidup. Sementara itu, sebagai bangsa Indonesia setiap dorongan dan pilihan harus dilandasi oleh pancasila (Rosidatun, 2018: 6). Upaya yang dilakukan secara sadar, terencana dan terarah melalui lingkungan saat pembelajaran untuk meningkatkan seluruh potensi manusia yang mempunyai kepribadian baik, bermoral, berakhlak, dan berdampak positif konstruktif pada alam dan masyarakat disebut pendidikan karakter (Islam, 2017: 99). Sedangkan Menurut Chusnani (2013: 11), Pendidikan karakter merupakan upaya-upaya yang dirancang dan dilaksanakan secara sistematis untuk membantu peserta didik dalam memahami nilai-nilai perilaku manusia yang berhubungan dengan Tuhan Yang Maha Esa, diri sendiri, sesama manusia, lingkungan, dan kebangsaan yang diimplementasikan dalam pikiran, sikap, perasaan, perkataan, dan perbuatan berdasarkan norma-norma agama, hukum, tata krama, budaya, dan adat istiadat.

Kemampuan berpikir kreatif dapat diperoleh dari interaksi antara seseorang dan lingkungannya. Lingkungan sangat berperan terhadap kemampuan berpikir kreatif seseorang. Implikasinya adalah kemampuan berpikir kreatif dapat ditingkatkan melalui pendidikan (Sari, dkk, 2013: 61). Kreativitas merupakan salah satu indikator yang memegang peranan penting dalam pencapaian keberhasilan belajar siswa melalui pembelajaran (Wilda,dkk, 2017: 138). Ciri-ciri kreativitas antara lain memiliki rasa ingin tahu yang tinggi, aktif mengajukan pertanyaan yang berbobot, memberikan banyak gagasan dan solusi terhadap suatu masalah, mampu menyatakan pendapat secara spontan dan percaya diri, idealisme dalam menyampaikan pendapat, tidak mudah terpengaruh orang lain, mampu mengajukan pemikiran,, dapat bekerja sendiri dan senang mencoba hal-hal baru. Aspek-aspek aptitude dari kreativitas meliputi kelancaran, keluwesan, fleksibilitas dan orisinalitas dalam berpikir sedangkan aspekaspek non-aptitude atau afektif dari kreativitas meliputi kepercayaan diri, keuletan, apresiasi dan kemandirian (Fajriah, 2012: 1-2). Kemampuan berpikir kreatif siswa perlu ditingkatkan di sekolah dengan memberikan kesempatan kepada siswa untuk menyampaikan ide-ide yang dimilikinya (Abdurrozak, dkk, 2016: 872).

Sikap dalam pembelajaran sangatlah penting, begitu pula sikap yang ada pada pembelajaran terhadap mata pelajaran disekolah (Darmawangsa, dkk: 108). Sikap adalah pikiran dan perasaan yang mendorong kita bertingkah laku ketika kita menyukai atau tidak menyukai sesuatu. Pengukuran terhadap sikap dikategorikan melalui tiga cara, yaitu wawancara, observasi, dan kuesioner. Instrumen sikap untuk mengetahui sikap siswa terhadap suatu objek (Hardiyanti, dkk, 2018: $3)$. Peserta didik yang memiliki sikap ilmiah yang tinggi akan membantu proses pembalajaran sains terutama bidang fisika menjadi lebih baik. Hal ini dikarenakan sikap ilmiah dapat membentuk peserta didik berfikir secara kreatif dan kritis (Astalini, dkk, 2019: $37)$.

Untuk menilai karakter peserta didik dalam hal kreativitas siswa, maka penulis melakukan penelitian terhadap siswa SMP Negeri 08 Kota Jambi. Penelitian dilakukan dengan mengambil data pada dua kelas VIII yang berbeda, yaitu kelas VIII C dan VIII E. 
Penelitian dilakukan dengan memberikan angket kepada siswa dengan 25 pernyataan tentang kreativitas. Penelitian ini bertujuan untuk membandingkan hasil kedua kelas tersebut dan melihat tingkat kreativitas siswa di SMP Negeri 08 Kota Jambi dalam proses pembelajaran.

\section{METODE PENELITIAN}

Penelitian ini dilakukan di SMP Negeri 08 Kota Jambi yang terletak di Jalan Sunan Giri No.06, Simpang III Sipin, Kota Baru, Kota Jambi, Provinsi Jambi. Data sampel penelitian terdiri dari dua kelas yaitu kelas VIII $\mathrm{C}$ dan kelas VIII E dengan jumlah siswa masing-masing kelas 31 siswa dan 28 siswa. Penelitian ini menggunakan metode penelitian kuantitatif deskriptif. Metode penelitian kuantitatif deskriptif merupakan salah satu jenis penelitian yang mendeskripsikan suatu objek yang diteliti melalui data atau sampel dalam kondisi apa adanya tersusun secara sistematis, terencana dan terstruktur. Menurut Hamdi dan Bahruddin (2014: 5), menyatakan bahwa penelitian deskriptif (descriptive research) merupakan suatu metode penelitian yang menggambarkan fenomena-fenomena yang ada di lingkungan, yang berlangung pada saat sekarang maupun saat lampau. Metode penelitian deskriptif tidak hanya dapat rnendeskripsikan sesuatu keadaan saja, tetapi juga mendeskripsikan keadaan melalui tahapan-tahapan perkembangannya. Penelitian ini tidak melakukan perubahan variabelvariabel bebas, tetapi menggambarkan suatu kondisi apa adanya dengan menggunakan angka-angka yang dapat dilakukan secara individual atau kelompok.

Menurut Nuraeni (2016: 248), Teknik pengambilan sampel menggunakan total sampling yaitu jumlah sampel sama dengan populasi. Sehingga total sampel penelitian ini berjumlah 59 orang siswa terdiri dari kelas VIII C dan VIII E pada SMP N 08 Kota Jambi. Waktu penyebaran dilakukan di bulan Maret 2019 yang dimulai tanggal 26 Maret. Berikut data hasil yang diperoleh dari penyebaran instrumen angket atau kuisioner. Hasil pada angket kemudian diubah kedalam bentuk angka dengan skala 1 sampai 4 untuk dianalisis atau dihitung persentasenya lalu diintrepetasikan sesuai dengan kategori yang sudah ditentukan.

Penelitian ini juga menggunakan jenis penelitian survei. Penelitian survei adalah salah satu jenis penelitian dengan pengambilan datanya menggunakan pertanyaan-pertanyaan tertulis, bukan pertanyaan lisan (Rukajat, 2018:143). Penelitian dilakukan dengan cara mengumpulkan data menggunakan instrumen penilaian tes berupa tes kuisioner. Jenis instrument tes kuisioner yang dipilih ialah angket dengan menggunakan variable karakter kreativitas. Jenis angket yang digunakan bersifat tertutup karena berupa pernyataan mengenai kesadaran siswa terhadap kreatiuvitas dalam pembelajaran. Angket penelitian ini diadopsi dari skripsi (Syafri,2017) terdiri dari 40 pernyataan yang telah lulus uji validasi dan reabilitas. Namun dalam penelitian ini hanya diadopsi 25 butir pernyataan. Hal ini dilakukan untuk mengetahui karakter kreativitas siswa.

Tes ini juga menggunakan 4 skala likert yaitu Selalu (SL), Sering (SR), Jarang (JR), dan Tidak Pernah (TP) dengan 5 indikator yaitu waktu, kesempatan, dorongan, sarana, dan pengetahuan. Skala likert diterapkan untuk mempermudah proses perhitungan hasil akhir. Angket ini disebarkan ke dua kelas yang berbeda namun dalam tingkatan yang sama yaitu kelas VIII C dan kelas VIII E.Data yang diperoleh diolah dan dianalisis menggunakan software pengolahan data SPSS. Di mana nilai untuk skala terbagi menjadi 4 kategori, yaitu: skala 4 untuk kategori selalu, skala 3 untuk kategori sering, skala 2 untuk kategori jarang dan skala 1 untuk kategori tidak pernah

Penelitian ini bertujuan untuk mengetahui karakter kreativitas siswa SMP Negeri 08 Kota Jambi terhadap proses pembelajaran IPA. Selain itu, untuk merencanakan hal yang akan dilakukan untuk memperbaiki karakter siswa masih dianggap belum cukup. Dengan dilakukannya penelitian ini, diharapkan dapat membantu dan memperluas pengetahuan pribadi peneliti dan peneliti lain dalam melakukan penelitian, serta membantu semua pihak yang terlibat didalam dunia pendidikan untuk memperbaiki proses pembelajaran.

\section{HASIL \& PEMBAHASAN}

\section{Hasil}

Hasil analisis statistik deskriptif yang diperoleh menggunakan software pengolahan data SPSS mengenai angket karakter kreativitas siswa-siswi kelas VIII C dan VIII E pada SMP 08 Kota Jambi dapat dilihat pada tabel berikut : 
Tabel 1. Statistik Deskriptif Angket

Karakter "Kreativitas" siswa-siswi kelas VIII C SMPN 08 Kota Jambi

\begin{tabular}{ll}
\hline Parameter & Hasil \\
\hline Mean & 58,97 \\
Median & 59 \\
Modus & 64 \\
Standar Deviasi & 8,62 \\
Rentang & 44 \\
Minimum & 38 \\
Maksimum & 82 \\
\hline
\end{tabular}

Tabel 2. Statistik Deskriptif Angket Karaker "Kreativitas" siswa-siswi kelas VIII E SMPN 08 Kota Jambi

\begin{tabular}{ll}
\hline Parameter & Hasil \\
\hline Mean & 63,64 \\
Median & 65 \\
Modus & 65 \\
Standar Deviasi & 10,24 \\
Rentang & 51 \\
Minimum & 38 \\
Maksimum & 89 \\
\hline
\end{tabular}

Adapun Klasifikasi Angket Karakter "Kreativitas" siswa-siswi kelas VIII C SMPN 08 Kota Jambi sebagai berikut :

Tabel 3. Klasifikasi Angket Karakter "Kreativitas" siswa kelas VIII C SMPN 08 Kota Jambi

\begin{tabular}{clcc}
\hline \multicolumn{1}{c}{ Skor } & Kategori & Frekuensi & $\begin{array}{c}\text { Persentase } \\
(\%)\end{array}$ \\
\hline $25-43,75$ & Sangat & 1 & 3,2 \\
& Tidak Baik & & \\
$43,76-62,5$ & Tidak Baik & 18 & 58,1 \\
$62,6-81,25$ & Baik & 11 & 35,5 \\
$81,26-100$ & Sangat & 1 & 3,2 \\
& Baik & & \\
\end{tabular}

Jumlah 31 100

Tabel 4. Klasifikasi Angket Karakter "Kreativitas" siswa-siswi kelas VIII E SMPN 08 Kota Jambi

\begin{tabular}{clcc}
\hline Skor & Kategori & Frekuensi & $\begin{array}{c}\text { Persentase } \\
(\mathbf{\%})\end{array}$ \\
\hline $25-43,75$ & Sangat & 1 & 3,6 \\
& Tidak Baik & & \\
$43,76-62,5$ & Tidak Baik & 9 & 32,1 \\
$62,6-81,25$ & Baik & 17 & 60,7 \\
$81,26-100$ & Sangat & 1 & 3,6 \\
& Baik & & \\
\hline \multicolumn{2}{c}{ Jumlah } & $\mathbf{2 8}$ & $\mathbf{1 0 0}$ \\
\hline
\end{tabular}

\section{Pembahasan}

Analisis karakter kreativitas yang dimiliki oleh siswa-siswi di SMP N 08 Kota Jambi khususnya kelas VIII C dan VIII E dapat diidentifikasi menggunakan SPSS dengan parameter berupa mean, median, modus, standar deviasi, rentang, nilai minimum dan nilai maksimum. Selain itu, untuk mengidentifikasi tingkat kreativitas siswa-siswa menggunakan skala likert dan dapat mengklasifikasikan menggunakan SPSS berdasarkan skor, kategori, frekuensi dan persentasi valid.

Berdasarkan data hasil pada Tabel 1. yaitu data angket kreativitas siswa-siswi kelas VIII C menyatakan bahwa nilai rata-rata (mean) dari 31 responden sebesar 58,97. Sedangkan nilai tengah (median) sebesar 59 dan nilai yang sering muncul (modus) sebesar 64. Adapun standar deviasi adalah sebesar 8,62 dengan rentang sebesar 44. Sehingga diperoleh nilai minimum sebesar 38 dan nilai maksimum sebesar 82. Untuk menganalisis data tersebut, dapat dilihat dari nilai rata-rata dan standar deviasi. Dari data tersebut nilai rata-rata sebesar 58,97 menyatakan bahwa nilai tersebut termasuk kategori "Tidak Baik". Selain itu dengan standar deviasi sebesar 8,62 menyatakan bahwa data tersebut valid karena apabila nilai standar deviasi lebih kecil dari nilai rata-rata yaitu $8,62<58,97$. Menurut Kurniawan, dkk (2018: 130), Apabila nilai standar deviasi lebih kecil dari mean, berarti nilai mean merupakan representasi dari seluruh sampel data penelitian sehingga dapat dikatakan bahwa data penelitian valid. Berdasarkan hasil data tersebut, dapat disimpulkan bahwa tingkat karakter kreativitas siswa-siswa kelas VIII C dikategorikan "Tidak Baik" atau dapat dikatakan tingkat kreativitas siswa-siswi kelas VIII C masih rendah.

Namun, kita perlu meninjau kembali dari segi penilaian skala likert. Berdasarkan data pada Tabel 3, diperoleh data bahwa terdapat 1 siswa yang menjawab angket kategori Sangat Tidak Baik dengan persentasi sebesar 3,2 \%, 18 siswa-siswi yang menjawab angket kategori Tidak Baik dengan persentase sebesar 58,1 \%, tetapi ada 11 siswa yang menjawab angket kategori Baik dengan persentase sebesar 35,5 \% dan 1 siswa menjawab angket kategori Sangat Baik dengan persentasi $3,2 \%$. Berdasarkan data tersebut, dapat disimpulkan bahwa tingkat kreativitas siswa-siswi kelas VIII C rata-rata tergolong "Tidak Baik" dengan persentase tertinggi sebesar 58,1 \% tetapi ada beberapa yang 
tergolong "Baik" dengan persentase sebesar $35,5 \%$. Penentuan skor terendah dan tertinggi diperoleh dari jumlah pernyataan angket sebanyak 25. Sehingga dapat dikategorikan skor terendah adalah 25 dan tertinggi adalah 100. Adapun frekuensi dan persentase untuk setiap kategori dapat diolah dengan menggunakan software pengolahan data SPSS.

Berdasarkan data hasil pada Tabel 2. yaitu data angket kreativitas siswa-siswi kelas VIII E menyatakan bahwa nilai rata-rata (mean) dari 28 responden sebesar 63,64. Sedangkan nilai tengah (median) sebesar 64 dan nilai yang sering muncul (modus) sebesar 65. Adapun standar deviasi adalah sebesar 10,24 dengan rentang sebesar 51. Sehingga diperoleh nilai minimum sebesar 38 dan nilai maksimum sebesar 89. Untuk menganalisis data tersebut, dapat dilihat dari nilai rata-rata dan standar deviasi. Dari data tersebut nilai rata-rata sebesar 63,64 menyatakan bahwa nilai tersebut termasuk kategori "Baik". Selain itu dengan standar deviasi sebesar 10,24 menyatakan bahwa data tersebut valid karena apabila nilai standar deviasi lebih kecil dari nilai rata-rata yaitu $10,24<63,64$. Berdasarkan hasil data tersebut, dapat disimpulkan bahwa tingkat karakter kreativitas siswa-siswa kelas VIII E dikategorikan "Baik" atau dapat dikatakan tingkat kreativitas siswa-siswi kelas VIII E sedang.

Namun, kita perlu meninjau kembali dari segi penilaian skala likert. Berdasarkan data pada Tabel 4, diperoleh data bahwa terdapat 1 siswa yang menjawab angket kategori Sangat Tidak Baik dengan persentasi sebesar 3,6 \%, 9 siswa-siswi yang menjawab angket kategori Tidak Baik dengan persentase sebesar 32,1 \%, tetapi ada 17 siswa yang menjawab angket kategori Baik dengan persentase sebesar $60,7 \%$ dan 1 siswa menjawab angket kategori Sangat Baik dengan persentasi 3,6 \%. Berdasarkan data tersebut, dapat disimpulkan bahwa tingkat kreativitas siswa-siswi kelas VIII E rata-rata tergolong

\section{KESIMPULAN \& SARAN}

\section{Kesimpulan}

Berdasarkan hasil analisis data berupa angket karakter kreativitas terhadap siswa kelas VIII C dan VIII E pada SMPN 08 Kota Jambi, dapat disimpulkan bahwa tingkat kreativitas siswa berbeda-beda. Hal ini terbukti tingkat kreativitas siswa kelas VIII C tergolong kategori "Tidak Baik" atau rendah sedangkan tingkat kreativitas kelas VIII E tergolong
"Baik" dengan persentase tertinggi sebesar $60,7 \%$ tetapi ada yang masih tergolong "Tidak Baik" dengan persentase sebesar 32,1\%. Penentuan skor terendah dan tertinggi diperoleh dari jumlah pernyataan angket sebanyak 25. Sehingga dapat dikategorikan skor terendah adalah 25 dan tertinggi adalah 100. Adapun frekuensi dan persentase untuk setiap kategori dapat diolah dengan menggunakan software pengolahan data SPSS.

Pentingnya kreativitas dalam bidang pendidikan saat ini tidak dapat oleh kalangan pendidik terutama peserta didik. Kreativitas memberikan kesempatan pada setiap individu dalam mencari solusi dalam menghadapi suatu tantangan atau masalah yang tentunya tidak harus terfokus pada kebiasaan yang masih beralngsung. Menurut Raka,dkk (2013: 14), Kreativitas merupakan suatu proses mental pada seseorang dalam upaya menghasilkan gagasan, proses, ide, metode ataupun suatu hal baru yang bersifat efektif, imajinatif, estetis, integrasi, dan berdaya guna dalam berbagai bidang untuk mmemecahkan suatu permasalahan. Adapun proses kreatif akan terjadi apabila bersifat lancer, luwes, asli, terperinci dan peka dalam memecahkan suatu masalah.

Perkembangan teknologi yang dialami saat ini seharusnya dapat menambah dampak positif pada karakter anak bangsa akan tetapi sebaliknya, pendidikan karakter semakin terabaikan. Padahal pendidikan karakter adalah suatu pondasi bangsa yang sangat berperan penting dan perlu diterapkan sejak dini. Jika kita mendidik anak dengan cara yang baik dan selalu ada hal baru yang bsersifat positif dan membangun tentunya akan menghasilkan generasi penerus bangsa yang berkarakter dan memiliki ide kreatif untuk memajukan bangsa ini. Oleh karena itu, implementasi pendidikan karakter perlu ditingkatkan dan dapat dilakukan baik di lingkungan keluarga, sekolah, maupun lingkungan masyarakat.

kategori "Baik" atau sedang. Adapun hasil analisis sata ini dibuktikan menggunakan SPSS dengan metode penelitian deskriptif kuantitatif. Adapun hasil yang diperoleh pada kelas VIII C, yaitu nilai rata-rata (mean) dari 31 responden sebesar 58,97 dan standar deviasi adalah sebesar 8,62. Sedangkan berdasarkan klasifikasi dari skala angket diperoleh data bahwa terdapat 18 siswa-siswi yang menjawab angket kategori Tidak Baik dengan persentase tertinggi sebesar 58,1 \%. Adapun hasil yang 
diperoleh dari kelas VIII E, yaitu nilai rata-rata (mean) dari 28 responden sebesar 63,64 dan standar deviasi adalah sebesar 10,24. Sedangkan berdasarkan klasifikasi dari skala angket diperoleh data bahwa terdapat 17 siswa yang menjawab angket kategori Baik dengan persentase tertinggi sebesar $60,7 \%$.

\section{Saran}

Melalui penelitian ini, peneliti sangat menyadari bahwa penerapan nilai karakter khususnya karakter kreativitas sangat penting untuk diterapkan pada diri siswa-siswi smp bahkan lebih baik jika diterapkan sejak dini. Untuk memahaminy, tentu sangat diperlukan sumber pendukung lainnya. Oleh karena out, peneliti berharap tulisan ini dapat membuat dijadikan sebagai bahan tambahan dalam penulisan suatu artikel bagi para peneliti lainnya. Hal ini bertujuan agar peneliti lebih mendalami pemahaman mengenai karakter kreativitas siswa.

\section{DAFTAR PUSTAKA}

Abdurrozak, Rizal., Jayadinata, Asep Kurnia., dan Isrok 'atun. (2016). Pengaruh Model Problem Based Learning Terhadap Kemampuan Berpikir Kreatif Siswa. Jurnal Pena Ilmiah, 1(1), 872.

Astalini., Kurniawan, Dwi Agus., Rahmat, Perdana., dan Pathoni, Haerul. (2019). Identifikasi Sikap Peserta Didik terhadap Mata Pelajaran Fisika di Sekolah Menengah Atas Negeri 5 Kota Jambi. Unnes Physics Education Journal, 8(1), 37.

Chusnani, Diana. (2013). Pendidikan Karakter Melalui Sains. Jurnal Kebijakan dan Pengembangan Pendidikan, 1(1), 11.

Darmawangsa , Rio., Astalini., dan Kurniawan, Dwi Agus. Pengembangan Instrumen Sikap Siswa Sekolah Menengah Atas terhadap Mata Pelajaran Fisika. Jurnal Pendidikan Fisika Universitas Muhammadiyah Makassar, 6(1), 108.

Fajriah, Noor., Sukmawati, R Ati., dan Megawati, Tisna. (2012). Meningkatkan Kreativitas Siswa Kelas Viii C Smp Negeri 24 Banjarmasin Melalui Model Problem Based Instruction Dengan Pendekatan Open-Ended Tahun Pelajaran 2011/2012. Jurnal Edumatica, 2(2), 1-2.

Hamdi, Asep Saepul., dan Bahruddin, E. (2014). Metode Penelitian Kuantitatif Aplikasi dalam Pendidikan. Yogyakarta: Deepublish : CV Budi Utama.
Hardiyanti, Kiki., Astalini., dan Kurniawan, Dwi Agus. (2018). Sikap Siswa Terhadap Mata Pelajaran Fisika Di SMANegeri 5 Muaro Jambi. Jurnal Edufisika, 3(2), 3.

Islam, Syaiful. (2017). Karakteristik Pendidikan Karakter; Menjawab Tantangan Multidimensional Melalui Implementasi Kurikulum 2013. Jurnal Edureligia, 1(1), 99.

Kurniawan, Dwi Agus., Astalini., dan Anggraini, Lika. (2018). Evaluasi Sikap Siswa Smp Terhadap Ipa Di Kabupaten Muaro Jambi. Jurnal Ilmiah DIDAKTIKA, 19(1),130.

Nuraeni, Afiah. (2016). Peran Orang Tua Dalam Pengembangan Literasi Dini Anak Kelompok B di Gugus 7 Mangunan Dlingo Bantul. Jurnal Pendidikan Anak Usia Dini Edisi 3, 248.

Puti, Siska., dan Jumadi, Jumadi. (2015). Pengembangan Modul IPA SMP Berbasis Guided Inquiry untuk Meningkatkan Keterampilan Proses dan Sikap Ilmiah. Jurnal Pendidikan Matematika dan Sains, 3(1), 80.

Rahayu, Rina., dan Laksono, Endang W. (2015). Pengembangan Perangkat Pembelajaran IPA Berbasis ProblemBased Learning di SMP. Jurnal Kependidikan. 45(1), 30.

Raka, Gede., Mulyana, Yoyo., Markam, Suprapti Sumarmo., Semiawan, Conny R., Hasan, Sid Hamid., Bastaman, Hana Djumhana., dan Nurachman, Nani. (2013). Pendidikan Karakter di Sekolah: Seri Pendidikan Karakter Yayasan Jati Diri Bangsa : Elex Media Komputindo.

Rosidatun. (2018). Model Implementasi Pendidikan Karakter. Gresik : Caremedia Communication.

Rukajat, Ajat. (2018). Pendekatan Penelitian Kuantitatif. Yogyakarta: Deepublish.

Sari, Ika Mulia., Evi, Sumiati., dan Parsaoran, Siahaan. (2013). Analisis Kemampuan Berpikir Kreatif Siswa Smp Dalam Pembelajaran Pendidikan Teknologi Dasar (PTD). 61.

Siagian, Roida Eva Flora., dan Nurfitriyanti, Maya. (2015). Metode Pembelajaran Inquiry Dan Pengaruhnya Terhadap Hasil Belajar Matematika Ditinjau Dari Kreativitas Belajar. Jurnal Formatif, 2(1), 37.

Sumarni,S., Santoso, Bimo Budi., dan Suparman, Achmad Rante. (2017). 
Pengaruh Model Pembelajaran Inkuiri Terbimbing Terhadap Hasil Belajar Kognitif Peserta Didik Di SMA Negeri 01 Manokwari (Studi Pada Pokok Bahasan Kelarutan Dan Hasil Kali Kelarutan). Jurnal Nalar Pendidikan, 5(1), 21.

Syafri. (2017). Analisis Faktor-faktor yang mempengaruhi Kreativitas Siswa Kelas XI SMK Negeri 4 Muaro Jambi. Skripsi. Jambi : Universitas Jambi.

Taufik, Mohammad, N., Sukmadinata, S., Ishak., Abdulhak., dan Tumbelaka, Bernard Y. (2010). Desain Model Pembelajaran Untuk Meningkatkan Kemampuan Pemecahan Masalah Dalam Pembelajaran Ipa (Fisika) Sekolah Menengah Pertama Di Kota Bandung. Jurnal Berkala Fisika, 13(2), 33.

Taufiq, M., Dewi, N. R., dan Widiyatmoko, A. (2014). Pengembangan Media Pembelajaran Ipa Terpadu Berkarakter Peduli Lingkungan Tema "Konservasi" Berpendekatan Science-Edutainment. Jurnal Pendidikan IPA Indonesia, 3(2), 141.

Wilda., Salwah., dan Ekawati, Shindy (2017). Pengaruh Kreativitas Dan Minat Belajar Terhadap Hasil Belajar Matematika Siswa. Pedagogy : Journal of Mathematichs Education, 2(1), 138. 